\title{
Review
}

\section{Regulation of Cell Growth and Apoptosis by Adrenomedullin}

\author{
Masayoshi SHICHIRI and Yukio HIRATA*
}

\begin{abstract}
Adrenomedullin, originally discovered in human pheochromocytoma, has been shown to have potent vasodilatory activity. However, like other vasoactive peptide hormones, its physiological roles have been found to extend far beyond the regulation of vascular tonus, and to include such functions as the regulation of cell proliferation and differentiation. There is a growing body of evidence that adrenomedullin exerts a wide range of effects on cell growth and apoptotic death, and that these effects are dependent on cell type and experimental conditions. Signaling pathways independent of cyclic AMP, such as protein tyrosine kinase(s) and mitogen-activated protein kinases, may play key roles in the regulation of mitogenesis and apoptosis by adrenomedullin. (Hypertens Res 2003; 26 (Suppl): S9-S14)
\end{abstract}

Key Words: adrenomedullin, proliferation, apoptosis, vascular cells

\section{Introduction}

Adrenomedullin was originally isolated from human pheochromocytoma based on its ability to raise intracellular cyclic (c)AMP levels in platelets (1). Adrenomedullin belongs to a calcitonin supergene family that includes calcitonin gene-related peptide (CGRP) and amylin (2, 3). Although initially identified as a potent vasodilator peptide, subsequent studies have demonstrated that adrenomedullin exerts diverse biological actions, such as diuresis/natriuresis (4-6), hormone secretion (7-9), cell growth, differentiation and apoptosis $(10-13)$.

Human adrenomedullin, synthesized from a 185-aminoacid preproadrenomedullin, is a 52-residue peptide with an intramolecular disulfide bridge and an amidated tyrosine residue at the carboxy terminus $(1,14)$. Preproadrenomedullin contains a 21-amino-acid signal peptide sequence that immediately precedes a 20 -amino-acid amidated peptide designated proadrenomedullin $\mathrm{NH}_{2}$-terminal 20 peptide (15). The gene encoding preproadrenomedullin, mapped on chromosome 11, is ubiquitously expressed. Many tumor cell lines also express the adrenomedullin mRNA and/or protein (12). Adrenomedullin has been shown to circulate in human blood (16); the normal plasma concentrations of adrenomedullin are low (1-10 pmol/l), but are elevated in several disease states, such as cardiovascular, renal, and respiratory disorders (17-19), suggesting that adrenomedullin is involved mainly in the regulation of blood pressure (17-20).

This review focuses specifically on the role of adrenomedullin in cell growth and apoptosis, and readers are therefore referred to other reviews for a more extensive discussion of other functions $(2,15,17,21)$.

\section{Regulation of Cell Growth by Adrenomedullin}

Soon after its initial discovery, adrenomedullin was shown to be expressed in human brain and pulmonary tumor tissues, as well as in several human cancer cells $(22,23)$. Subsequent studies have confirmed its production from a variety of human cancer cell lines $(12,24-26)$. Adrenomedullin has also been shown to act on tumor cell lines themselves, many of which express its receptors $(12,25,27)$. An autocrine/paracrine growth-promoting activity has been implicated in adrenomedullininduced mitogenesis in several cancer cell lines $(12,25)$. An autocrine role of adrenomedullin has been recognized as essential for tumorigenesis (28).

Adrenomedullin has been expressed and synthesized in a

From the Department of Clinical and Molecular Endocrinology, Tokyo Medical and Dental University Graduate School, Tokyo, Japan.

Address for Reprints: Masayoshi Shichiri, M.D., Department of Clinical and Molecular Endocrinology, Tokyo Medical and Dental University Graduate School, 1-5-45, Yushima, Bunkyo-ku, Tokyo 113-8519, Japan. E-mail: mshichiri.cme@tmd.ac.jp

Received August 7, 2002; Accepted in revised form September 3, 2002. 
A

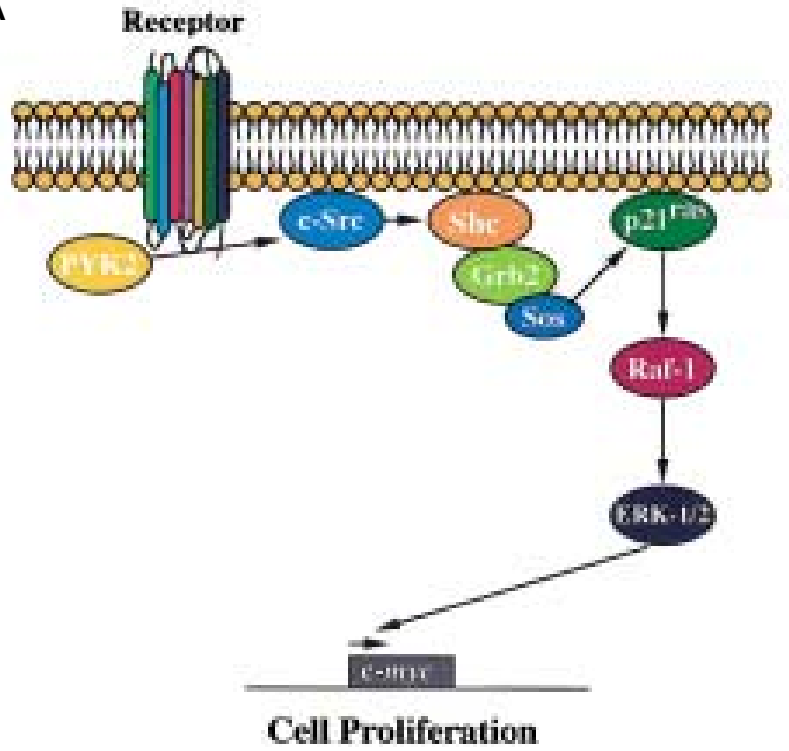

B

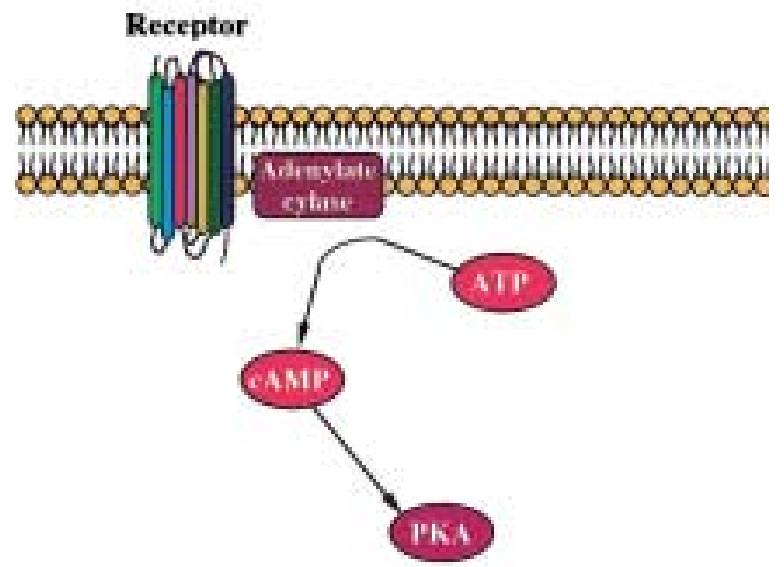

Growth Inhibition

Fig. 1. Signaling pathways of the cell-growth regulating activity of adrenomedullin. A: Adrenomedullin-induced cell proliferative response in VSMCs is mediated via activation of protein tyrosine kinase-MAPK. B: In cells lacking MAPK activation signaling pathways, stimulation of adrenomedullin receptors results in activation of $c A M P$, leading to growth inhibition.

variety of tissues and cells in the cardiovascular system (17). Expression of adrenomedullin and its functional receptors in vascular endothelial cells (29-31), vascular smooth muscle cells (VSMCs) $(32,33)$, and fibroblasts (34) suggests the autocrine/paracrine mode of its vascular effects. Endothelial cells are considered to be an important source of plasma adrenomedullin, and adrenomedullin induces endothelial NO generation and other actions in the vascular system (17).

It has been suggested that adrenomedullin plays a role in angiogenesis in vivo. In adrenomedullin gene knockout mice, the null phenotype is embryonically lethal due to the absence of placental vascularization; the basement membrane is absent in the aorta and cervical artery, and the endothelial cells are detached from the basement structure (35). These results suggested that adrenomedullin is essential for the vascular morphogenesis during embryonic development, although endothelial cells are present in adrenomedullin null mice. An in vitro cell culture experiment has also suggested that adrenomedullin is not involved in either stimulation of cell proliferation or induction of DNA synthesis in endothelial cells (11).

Adrenomedullin appears to either stimulate or inhibit cell proliferation depending on the particular cell type. With respect to the effects of adrenomedullin on VSMCs, studies have reported conflicting results. An initial report suggested that adrenomedullin had an antiproliferative effect; i.e., in serum-stimulated, growing VSMCs, addition of adrenomedullin suppressed thymidine incorporation, and this effect appeared to be mediated by cAMP stimulation (36). A recent study suggested that adrenomedullin antagonized platelet-derived growth factor (PDGF)-stimulated mitogenesis in a subpopulation of VSMCs from the pulmonary artery, but not in other VSMCs (37). On the other hand, adrenomedullin exerts a potent mitogenic effect in serum-deprived VSMCs $(10,38)$. When rendered quiescent by serum deprivation, VSMCs respond to adrenomedullin by synthesizing DNA and proliferating. These responses are independent of cAMP activation, but mediated by initial protein tyrosine phosphorylation and subsequent $\mathrm{p} 42 / \mathrm{p} 44$ mitogen-activated protein kinase (MAPK) activation (10). Adrenomedullin has been shown to rapidly and transiently phosphorylate proline-rich tyrosine kinase 2 (PYK2) via autophosphorylation; in the same study, adrenomedullin promoted the association between tyrosine-phosphorylated PYK2 and the adaptor proteins Shc and Grb2, activated c-Src, and enhanced the association between $\mathrm{c}$-Src and tyrosine-phosphorylated PYK2 (38). These observations suggest that adrenomedullin stimulates PYK2 which, in turn, activates c-Src and induces recruitment of adaptor proteins (Shc/Grb2), thereby leading to activation of the Ras-dependent MAPK cascade in VSMCs (38) (Fig. 1A). Such features of adrenomedullin as the stimulation of mitogenesis in quiescent cells while suppressing cells in the $\mathrm{G}_{2} / \mathrm{M}$ phase of the cell cycle are characteristic of growth factors, although unlike most other growth factors, adrenomedullin appears to suppress VSMC growth via stimulation of cAMP.

An in vivo role of endogenous adrenomedullin in the neointima after angioplasty has been demonstrated by infusion of the adrenomedullin/CGRP receptor antagonist, CGRP(8-37), to rats (39). Following balloon injury of the common carotid arteries, the expression of adrenomedullin was elevated at 2 days and further enhanced in the hyperplastic intima at 7 days, while neointimal hyperplasia developed within 7 days. However, both adrenomedullin expression and neointimal thickening were markedly suppressed by treatment with $\operatorname{CGRP}(8-37)$. At 7 days after injury, 

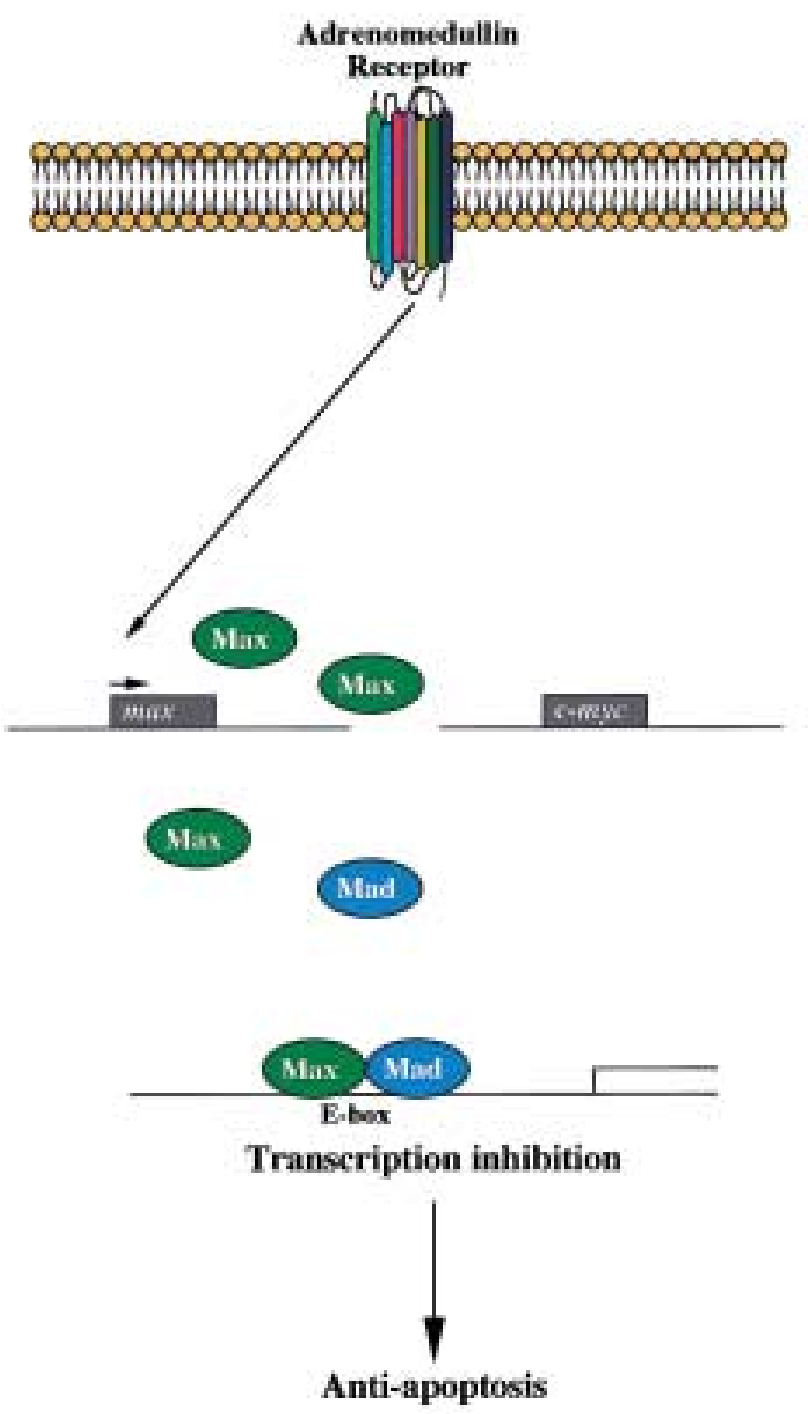

Fig. 2. Signaling of apoptosis by adrenomedullin in endothelial cells. Adrenomedullin protects against serum-deprivation-induced apoptosis by upregulating an antiapoptotic protein, max, independently from cAMP activation.

CGRP(8-37) reduced the neointimal cross-sectional area by $61 \%$, and BrdU-positive nuclei in the neointima were markedly reduced in CGRP(8-37)-treated arteries. The results suggest that inhibition of neointimal hyperplasia by CGRP(8-37) is mainly due to its blockade of endogenous adrenomedullin acting upon the proliferative VSMCs after balloon injury.

Accumulating lines of evidence support a role for adrenomedullin as a potent growth factor in a number of non-tumor cell types. These include fetal rat osteoblasts (40), neonatal mouse calvaria (40), rat adrenal zona glomerulosa cells $(41,42)$, fibroblasts $(34,43)$, and several epithelial cells of the normal skin, including keratinocytes of the epidermis and hair follicles, and the cells of the glands and secretory ducts (25). The mitogenic activity of adrenomedullin in many of the above-mentioned cells appears to be mediated via MAPK activation $(41,42)$.

An autocrine/paracrine role of adrenomedullin as a tumor growth factor has been more extensively studied $(12,44)$. Adrenomedullin synthesized and secreted from a variety of tumor tissues and cells $(12,22,24-26,45-47)$ stimulates the proliferation of skin tumors (25), oral squamous cell carcinoma (48), teratocarcinoma (49), Conn's adenoma cells (50), prostate cancer cells (51), non-small cell lung carcinoma (12, 22), breast carcinoma (12) and ovarian carcinoma (12).

Although there is overwhelming evidence that adrenomedullin promotes cellular growth, in certain cell types, there is also evidence that adrenomedullin suppresses mitogenesis. In rat mesangial cells, adrenomedullin inhibits mitogenesis even under quiescence and suppresses MAPK activity $(52,53)$. In cultured neonatal rat cardiocytes and cardiac fibroblasts, adrenomedullin suppresses cell growth $(54,55)$. Certain cancer cells do not proliferate in response to adrenomedullin, and some of these cell lines show a growth-inhibitory response with elevation of intracellular cAMP (56). Differential growth responses to adrenomedullin in each cell type and/or experimental condition appear to be dependent upon intracellular signaling machinery downstream of adrenomedullin receptors. For example, in cells lacking MAPK activation signaling machinery, stimulation of adrenomedullin receptors results in marked activation of cAMP, leading to inhibition of cell growth, while in the majority of cell types reported, the MAPK pathway is coupled to the adrenomedullin receptor, and the magnitude of growth stimulatory signaling exceeds the growth inhibitory signals by cAMP activation, thereby resulting in a net proliferative response (Fig. 1).

\section{Regulation of Apoptosis by Adrenomedullin}

Many cell types undergo apoptosis when they are deprived of growth factors, while addition of major growth factor(s), such as PDGF, insulin-like growth factor (IGF), basic fibroblast growth factor (bFGF) and epidermal growth factor (EGF), inhibits apoptosis. Various stimuli, such as serum deprivation, radiation, chemotherapeutic agents and antioxidants, induce apoptosis in many cell types (57-60), whereas growth factors and cytokines may modulate apoptosis triggered by such environmental signals (61-66). Within individual growth factors, the potency for inducing cell division is not always equal to that for antagonizing apoptosis whereas some growth factors may induce cell division without antagonizing apoptosis, or vice versa, and thus these two effects are considered discrete cell-survival factors. However, it has recently been revealed that even vasoactive peptides possessing mitogenic activity also show antiapoptotic activity. For example, endothelin-1 was the first peptide to be shown to inhibit serum-deprivation-induced apoptosis in endothelial cells (67), diploid fibroblasts (68), and VSMCs (69).

Almost simultaneously with our initial discovery of anti- 
apoptosis by endothelin, adrenomedullin was shown to act as an autocrine/paracrine apoptosis survival factor for vascular endothelial cells, although its potency was slightly less than that of endothelin-1 (11). Protection of endothelial apoptosis by adrenomedullin is mediated via a cAMP-independent mechanism, based on the finding that agents capable of elevating or mimicking cAMP, such as forskolin or prostaglandin $\mathrm{I}_{2}$, did not inhibit apoptosis, whereas cAMP antagonists failed to block the adrenomedullin-induced antiapoptotic effect (11). Subsequent studies have confirmed that adrenomedullin has a similar antiapoptotic activity independent of cAMP in human umbilical endothelial cells (70). Recently, a novel mechanism for the antiapoptotic activity of adrenomedullin was documented in our laboratory. Using the real-time quantitative RT-PCR method, adrenomedullin was demonstrated to induce a helix-loop-helix leucine zipper protein, max, which is a heterodimeric partner of c-myc oncogene. Unlike other growth factors, adrenomedullin did not induce the c-myc oncogene in endothelial cells, and the resulting max dominance leads to resistance to apoptosis (13) (Fig. 2).

In endometrial cancer cells, adrenomedullin has been reported to increase resistance to hypoxia-induced apoptosis via an upregulation of the antiapoptotic protein, Bcl-2 (71). In human adrenal zona glomerulosa cells, adrenomedullin decreased apoptotic cell death (72). In glomerular mesangial cells, however, both adrenomedullin and cAMP agonists can induce apoptosis, and the effect appears to be mediated via activation of cAMP, since a protein kinase A (PKA) inhibitor has been shown to block apoptosis induced by adrenomedullin (73). p38 MAPK has also been proposed to mediate the proapoptotic effect of adrenomedullin in mesangial cells (74). Such proapoptotic activity of adrenomedullin is not a feature common to other types of cells, but appears to be restricted to mesangial cells, at least at the present moment. Thus, the exact spectrum of target cell types in which adrenomedullin modulates apoptosis remains to be determined. Furthermore, the mechanisms by which adrenomedullin mediates antiapoptotic vs. proapoptotic signaling will require further investigation.

The physiological significance of the antiapoptotic or proapoptotic effects of adrenomedullin remain to be determined. Since adrenomedullin is actively synthesized and secreted from the vasculature, it is hypothesized that the local adrenomedullin concentration under various pathological states may protect the vascular endothelial cells against many insults in an autocrine/paracrine manner. By contrast, since abnormal proliferation of glomerular mesangial cells leads to the development of several glomerular diseases, apoptotic elimination of mesangial cells by adrenomedullin may serve to prevent the occurrence of mesangial proliferation. It is possible that adrenomedullin could play beneficial roles in retarding endothelial injury and progression of renal disease.

\section{Concluding Remarks}

The ability to modulate both cellular proliferation and apoptosis has been recognized as one of the features of the multifunctional regulatory peptide, adrenomedullin (17). There has been extensive investigation into the regulation of mitogenesis by this peptide, with most of the results suggesting that adrenomedullin promotes cellular growth via the protein tyrosine kinase (PTK)/MAPK pathway, although it also shows a growth-inhibitory effect on certain cell types via a cAMP-dependent mechanism. The effect of adrenomedullin on apoptosis has been less intensively studied; adrenomedullin appears to antagonize apoptosis in the great majority of cells examined, whereas it may promote apoptosis in a few cell types. Thus, adrenomedullin may play a dual role either as a growth promoting/antiapoptotic factor or as a growth-inhibitory/proapoptotic factor in a cell-specific manner. Since vascular endothelial cells, VSMCs, fibroblasts and cardiomyocytes secrete adrenomedullin and express its receptors, an autocrine/paracrine role for adrenomedullin to regulate cell growth and apoptosis of the cardiovascular tissues has been suggested. Adrenomedullin utilizes several intracellular signaling pathways, such as cAMP, nitric oxide/cGMP and PTK/MAPK. Among these, PTK appears to play the key role in the regulation of cell growth and apoptosis by adrenomedullin.

\section{References}

1. Kitamura K, Kangawa K, Kawamoto M, et al: Adrenomedullin: a novel hypotensive peptide isolated from human pheochromocytoma. Biochem Biophys Res Commun 1993; 192: 553-560.

2. Wimalawansa SJ: Amylin, calcitonin gene-related peptide, calcitonin, and adrenomedullin: a peptide superfamily. Crit Rev Neurobiol 1997; 11: 167-239.

3. Muff R, Born W, Fischer JA: Calcitonin, calcitonin generelated peptide, adrenomedullin and amylin: homologous peptides, separate receptors and overlapping biological actions. Eur J Endocrinol 1995; 133: 17-20.

4. Ebara T, Miura K, Okumura M, et al: Effect of adrenomedullin on renal hemodynamics and functions in dogs. Eur J Pharmacol 1994; 263: 69-73.

5. Miura K, Ebara T, Okumura M, et al: Attenuation of adrenomedullin-induced renal vasodilatation by $\mathrm{N}^{\mathrm{G}}$-nitro L-arginine but not glibenclamide. Br J Pharmacol 1995; 115: 917-924.

6. Hirata Y, Hayakawa H, Suzuki Y, et al: Mechanisms of adrenomedullin-induced vasodilation in the rat kidney. $H y$ pertension 1995 ; 25: 790-795.

7. Samson WK, Murphy T, Schell DA: A novel vasoactive peptide, adrenomedullin, inhibits pituitary adrenocorticotropin release. Endocrinology 1995; 136: 2349-2352.

8. Nussdorfer GG: Paracrine control of adrenal cortical function by medullary chromaffin cells. Pharmacol Rev 1996; 48: 495-530.

9. Ehrhart BM, Hinson JP, Bornstein SR, Scherbaum WA, Vinson GP: Intraadrenal interactions in the regulation of 
adrenocortical steroidogenesis. Endocr Rev 1998; 19: 101-143.

10. Iwasaki H, Eguchi S, Shichiri M, Marumo F, Hirata Y: Adrenomedullin as a novel growth-promoting factor for cultured vascular smooth muscle cells: role of tyrosine kinase-mediated mitogen-activated protein kinase activation. Endocrinology 1998; 139: 3432-3441.

11. Kato H, Shichiri M, Marumo F, Hirata Y: Adrenomedullin as an autocrine/paracrine apoptosis survival factor for rat endothelial cells. Endocrinology 1997; 138: 2615-2620.

12. Miller MJ, Martinez A, Unsworth EJ, et al: Adrenomedullin expression in human tumor cell lines. Its potential role as an autocrine growth factor. J Biol Chem 1996; 271: 23345-23351.

13. Shichiri M, Kato H, Doi M, Marumo F, Hirata Y: Induction of Max by adrenomedullin and calcitonin gene-related peptide antagonizes endothelial apoptosis. Mol Endocrinol 1999; 13: 1353-1363.

14. Kitamura K, Sakata J, Kangawa K, Kojima M, Matsuo H, Eto T: Cloning and characterization of cDNA encoding a precursor for human adrenomedullin. Biochem Biophys Res Commun 1993; 194: 720-725.

15. Samson WK: Proadrenomedullin-derived peptides. Front Neuroendocrinol 1998; 19: 100-127.

16. Kitamura K, Ichiki Y, Tanaka M, et al: Immunoreactive adrenomedullin in human plasma. FEBS Lett 1994; 341: 288-290.

17. Hinson JP, Kapas S, Smith DM: Adrenomedullin, a multifunctional regulatory peptide. Endocr Rev 2000; 21: 138-167.

18. Kato J, Kitamura K, Matsui E, et al: Plasma adrenomedullin and natriuretic peptides in patients with essential or malignant hypertension. Hypertens Res 1999; 22: 61-65.

19. Kuriyama S, Kobayashi H, Tomonari H, et al: Circulating adrenomedullin in erythropoietin-induced hypertension. Hypertens Res 2000; 23: 427-432.

20. Shimosawa T, Kanozawa K, Nagasawa R, et al: Adrenomedullin amidation enzyme activities in hypertensive patients. $H y$ pertens Res 2000; 23: 167-171.

21. Jougasaki M, Burnett JJ: Adrenomedullin: potential in physiology and pathophysiology. Life Sci 2000; 66: 855-872.

22. Martinez A, Miller MJ, Unsworth EJ, Siegfried JM, Cuttitta F: Expression of adrenomedullin in normal human lung and in pulmonary tumors. Endocrinology 1995; 136: 4099-4105.

23. Satoh F, Takahashi K, Murakami O, et al: Adrenomedullin in human brain, adrenal glands and tumor tissues of pheochromocytoma, ganglioneuroblastoma and neuroblastoma. J Clin Endocrinol Metab 1995; 80: 1750-1752.

24. Takahashi K, Satoh F, Hara E, et al: Production and secretion of adrenomedullin from glial cell tumors and its effects on cAMP production. Peptides 1997; 18: 1117-1124.

25. Martinez A, Elsasser TH, Muro CC, et al: Expression of adrenomedullin and its receptor in normal and malignant human skin: a potential pluripotent role in the integument. Endocrinology 1997; 138: 5597-5604.

26. Takahashi K, Satoh F, Hara E, et al: Production and secretion of adrenomedullin by cultured choroid plexus carcinoma cells. J Neurochem 1997; 68: 726-731.

27. Martinez A, Miller MJ, Catt KJ, Cuttitta F: Adrenomedullin receptor expression in human lung and in pulmonary tumors. J Histochem Cytochem 1997; 45: 159-164.

28. Zhao Y, Hague S, Manek S, Zhang L, Bicknell R, Rees
MC: PCR display identifies tamoxifen induction of the novel angiogenic factor adrenomedullin by a non estrogenic mechanism in the human endometrium. Oncogene 1998; 16: 409-415.

29. Sugo S, Minamino N, Kangawa K, et al: Endothelial cells actively synthesize and secrete adrenomedullin. Biochem Biophys Res Commun 1994; 201: 1160-1166.

30. Ishihara $\mathrm{T}$, Kato $\mathrm{J}$, Kitamura $\mathrm{K}$, et al: Production of adrenomedullin in human vascular endothelial cells. Life Sci 1997; 60: 1763-1769.

31. Kato J, Kitamura K, Kangawa K, Eto T: Receptors for adrenomedullin in human vascular endothelial cells. Eur $J$ Pharmacol 1995; 289: 383-385.

32. Sugo S, Minamino N, Shoji H, et al: Production and secretion of adrenomedullin from vascular smooth muscle cells: augmented production by tumor necrosis factor- $\alpha$. Biochem Biophys Res Commun 1994; 203: 719-726.

33. Eguchi S, Hirata Y, Kano H, et al: Specific receptors for adrenomedullin in cultured rat vascular smooth muscle cells. FEBS Lett 1994; 340: 226-230.

34. Isumi Y, Minamino N, Katafuchi T, et al: Adrenomedullin production in fibroblasts: its possible function as a growth regulator of Swiss 3T3 cells. Endocrinology 1998; 139: 2552-2563.

35. Shindo T, Kurihara Y, Nishimatsu H, et al: Vascular abnormalities and elevated blood pressure in mice lacking adrenomedullin gene. Circulation 2001; 104: 1964-1971.

36. Kano H, Kohno M, Yasunari K, et al: Adrenomedullin as a novel antiproliferative factor of vascular smooth muscle cells. J Hypertens 1996; 14: 209-213.

37. Upton PD, Wharton J, Coppock H, et al: Adrenomedullin expression and growth inhibitory effects in distinct pulmonary artery smooth muscle cell subpopulations. Am J Respir Cell Mol Biol 2001; 24: 170-178.

38. Iwasaki H, Shichiri M, Marumo F, Hirata Y: Adrenomedullin stimulates proline-rich tyrosine kinase 2 in vascular smooth muscle cells. Endocrinology 2000; 142: 564-572.

39. Shimizu K, Tanaka H, Sunamori M, Marumo F, Shichiri M: Adrenomedullin receptor antagonism by calcitonin gene-related peptide(8-37) inhibits carotid artery neointimal hyperplasia after balloon injury. Circ Res 1999; 85: 1199-1205.

40. Cornish J, Callon KE, Coy DH, et al: Adrenomedullin is a potent stimulator of osteoblastic activity in vitro and in vivo. Am J Physiol 1997; 273: E1113-E1120.

41. Semplicini A, Ceolotto G, Baritono E, et al: Adrenomedullin stimulates DNA synthesis of rat adrenal zona glomerulosa cells through activation of the mitogen-activated protein kinase-dependent cascade. J Hypertens 2001; 19: 599-602.

42. Andreis PG, Markowska A, Champion HC, Mazzocchi G, Malendowicz LK, Nussdorfer GG: Adrenomedullin enhances cell proliferation and deoxyribonucleic acid synthesis in rat adrenal zona glomerulosa: receptor subtype involved and signaling mechanism. Endocrinology 2000; 141: 2098-2104.

43. Withers DJ, Coppock HA, Seufferlein T, Smith DM, Bloom SR, Rozengurt E: Adrenomedullin stimulates DNA synthesis and cell proliferation via elevation of cAMP in Swiss 3T3 cells. FEBS Lett 1996; 378: 83-87.

44. Pio R, Martinez A, Cuttitta F: Cancer and diabetes: two 
pathological conditions in which adrenomedullin may be involved. Peptides 2001; 22: 1719-1729.

45. Nakayama M, Takahashi K, Hara E, et al: Production and secretion of two vasoactive peptides, endothelin-1 and adrenomedullin, by a colorectal adenocarcinoma cell line, DLD-1. J Cardiovasc Pharmacol 1998; 31: S534-S536.

46. Kitamuro T, Takahashi K, Nakayama M, et al: Induction of adrenomedullin during hypoxia in cultured human glioblastoma cells. J Neurochem 2000; 75: 1826-1833.

47. Takahashi K, Nakayama M, Totsune K, et al: Increased secretion of adrenomedullin from cultured human astrocytes by cytokines. J Neurochem 2000; 74: 99-103.

48. Kapas S, Brown DW, Farthing PM, Hagi PE: Adrenomedullin has mitogenic effects on human oral keratinocytes: involvement of cyclic AMP. FEBS Lett 1997; 418: 287-290.

49. Moody TW, Coy D, Cuttitta F, Montuenga LM: Proadrenomedullin $\mathrm{NH}_{2}$-terminal 20 peptide (PAMP) and adrenomedullin bind to teratocarcinoma cells. Peptides 2000; 21: 101-107.

50. Forneris M, Gottardo L, Albertin G, Malendowicz LK, Nussdorfer GG: Expression and function of adrenomedullin and its receptors in Conn's adenoma cells. Int J Mol Med 2001; 8: 675-679.

51. Rocchi P, Boudouresque F, Zamora AJ, et al: Expression of adrenomedullin and peptide amidation activity in human prostate cancer and in human prostate cancer cell lines. Cancer Res 2001; 61: 1196-1206.

52. Chini EN, Choi E, Grande JP, Burnett JC, Dousa TP: Adrenomedullin suppresses mitogenesis in rat mesangial cells via cAMP pathway. Biochem Biophys Res Commun 1995; 215: 868-873.

53. Segawa K, Minami K, Sata T, Kuroiwa A, Shigematsu A: Inhibitory effect of adrenomedullin on rat mesangial cell mitogenesis. Nephron 1996; 74: 577-579.

54. Tsuruda T, Kato J, Kitamura K, et al: Adrenomedullin: a possible autocrine or paracrine inhibitor of hypertrophy of cardiomyocytes. Hypertension 1998; 31: 505-510.

55. Tsuruda T, Kato J, Kitamura K, et al: An autocrine or a paracrine role of adrenomedullin in modulating cardiac fibroblast growth. Cardiovasc Res 1999; 43: 958-967.

56. Ando K, Omi N, Shimosawa T, Fujita T: Proadrenomedullin N-terminal 20 peptide (PAMP) inhibits proliferation of human neuroblastoma TGW cells. FEBS Lett 1997; 413: 462-466.

57. Cohen JJ: Apoptosis: physiologic cell death. J Lab Clin Med 1994; 124: 761-765.

58. Evan GI, Wyllie AH, Gilbert CS, et al: Induction of apoptosis in fibroblasts by c-myc protein. Cell 1992; 69: 119-128.

59. Lin KT, Xue JY, Nomen M, Spur B, Wong PY: Peroxynitrite-induced apoptosis in HL-60 cells. J Biol Chem 1995; 270: $16487-16490$.

60. Sellins KS, Cohen JJ: Gene-induction by $\gamma$-irradiation leads to DNA fragmentation in lymphocytes. J Immunol 1987; 139: 3199-3206.

61. Colotta F, Borre A, Wang JM, et al: Expression of a mono- cyte chemotactic cytokine by human mononuclear phagocytes. J Immunol 1992; 148: 760-765.

62. Harrington EA, Bennett MR, Fanidi A, Evan GI: c-Myc-induced apoptosis in fibroblasts is inhibited by specific cytokines. EMBO J 1994; 13: 3286-3295.

63. Koury MJ, Bondurant MC: Erythropoietin retards DNA breakdown and prevents programmed death in erythroid progenitor cells. Science 1990; 248: 378-381.

64. Muta K, Krantz SB: Apoptosis of human erythroid colonyforming cells is decreased by stem cell factor and insulinlike growth factor I as well as erythropoietin. $J$ Cell Physiol 1993; 156: 264-271.

65. Yamaguchi Y, Suda T, Ohta S, Tominaga K, Miura Y, Kasahara T: Analysis of the survival of mature human eosinophils: interleukin-5 prevents apoptosis in mature human eosinophils. Blood 1991; 78: 2542-2547.

66. Yonish RE, Resnitzky D, Lotem J, Sachs L, Kimchi A, Oren M: Wild-type p53 induces apoptosis of myeloid leukaemic cells that is inhibited by interleukin-6. Nature 1991; 352: 345-347.

67. Shichiri M, Kato H, Marumo F, Hirata Y: Endothelin-1 as an autocrine/paracrine apoptosis survival factor for endothelial cells. Hypertension 1997; 30: 1198-1203.

68. Shichiri M, Sedivy JM, Marumo F, Hirata Y: Endothelin-1 is a potent survival factor for c-Myc-dependent apoptosis. Mol Endocrinol 1998; 12: 172-180.

69. Shichiri M, Yokokura M, Marumo F, Hirata Y: Endothelin1 inhibits apoptosis of vascular smooth muscle cells induced by nitric oxide and serum deprivation via MAP kinase pathway. Arterioscler Thromb Vasc Biol 2000; 20: 989-997.

70. Sata M, Kakoki M, Nagata D, et al: Adrenomedullin and nitric oxide inhibit human endothelial cell apoptosis via a cyclic GMP-independent mechanism. Hypertension 2000; 36: $83-88$.

71. Oehler MK, Norbury C, Hague S, Rees MC, Bicknell R: Adrenomedullin inhibits hypoxic cell death by upregulation of $\mathrm{Bcl}-2$ in endometrial cancer cells: a possible promotion mechanism for tumour growth. Oncogene 2001; 20: 2937-2945.

72. Rebuffat P, Forneris ML, Aragona F, Ziolkowska A, Malendowicz LK, Nussdorfer GG: Adrenomedullin and its receptors are expressed in the zona glomerulosa of human adrenal gland: evidence that ADM enhances proliferation and decreases apoptosis in cultured ZG cells. Int J Mol Med 2002; 9: 119-124.

73. Parameswaran N, Nambi P, Brooks DP, Spielman WS: Regulation of glomerular mesangial cell proliferation in culture by adrenomedullin. Eur J Pharmacol 1999; 372: 85-95.

74. Parameswaran N, Spielman WS, Brooks DP, Nambi P: SB203580 reverses adrenomedullin's effect on proliferation and apoptosis in cultured mesangial cells. Eur J Pharmacol 1999; 371: 75-82. 